\title{
The Productivity Commission: a different engine for law reform? ${ }^{\dagger}$
}

\author{
${\text { Lyria Bennett } \text { Moses }^{\mathrm{a}} \text { (D), Nicola Gollan }}^{\mathrm{a}}$ and Kieran Tranter ${ }^{\mathrm{b} *}$ \\ ${ }^{a}$ UNSW Australia Faculty of Law, Sydney, Australia; ${ }^{b}$ Socio-legal Research Centre, Griffith Law \\ School, Griffith University, Gold Coast, Australia
}

\begin{abstract}
This empirical study analyses the extent to which the Productivity Commission (Commission) relies on different types of evidence in formulating recommendations in a sample of reports. It goes deeper than traditional citation analysis; rather than classifying and counting all material cited in each sample report, it includes only citations that influenced the final recommendations. The findings, which run counter to the rhetoric employed in relation to the Commission's work, reveal the extent to which the Commission relies on nonquantitative forms of evidence, including bare assertions, personal experience, and logical and legal arguments, particularly in reports addressing broader questions of social policy. It concludes with a discussion of the significance of these findings, linking them to Graycar's critique of law reform commissions. As such, it provides a more accurate, but still preliminary, basis for understanding the Commission's methods than that otherwise appearing in the discourse surrounding the Commission's work.
\end{abstract}

\section{Introduction}

In Australia the Productivity Commission (Commission) plays an important role in recommending legislative changes in important areas such as access to justice, the design of regulatory schemes, trade law and patent licensing. While the idea of law reform and the methods used by law reform commissions have received a fair degree of scholarly attention, ${ }^{1}$ the Commission has remained largely unstudied, despite its international influence. Notwithstanding this scarcity, it has been suggested that in an era of 'evidence-based reform' the methods and approaches of the Commission presents a different engine for law reform commissions that the latter should consider adopting. ${ }^{2}$

This article will attempt to explore this possibility and fill the gap in scholarship on the Commission through an empirical analysis of a sample of reports to identify the sources and evidence the Commission actually relies on in formulating its recommendations. Through this analysis, this article aims to contribute to the literature on different institutional mechanisms for law reform by providing an empirically based understanding of methods employed by the Commission.

*Corresponding author. Email: k.tranter@griffith.edu.au

†The authors, who all contributed equally, are listed in alphabetical order.

${ }^{1}$ Eg Sutton (1970); Samek (1977); Kirby (1983); Hurlburt (1986); MacDonald (1997); Opeskin and Weisbrot (2005); Neave (2007); Barnett (2011).

${ }^{2}$ Tranter (2015), p 355 . 
The findings of our analysis were surprising. While the Commission is open about the extent to which it engages in extensive consultation, it has also claimed to be 'at the heart of evidence-based policy making in Australia'. ${ }^{3}$ Given its renown as a body offering objective and independent advice, the Commission might be expected to rely primarily on economic or empirical analysis. However, we found that it relied more heavily on stakeholder viewpoints than on such objective evidence in justifying recommendations in its reports. In this, its approach is not dissimilar to the identified approach of the Australian Law Reform Commission (ALRC). ${ }^{4}$

The implications of our finding a difference between rhetoric surrounding the Commission and its actual approach means that popular views about the role and approach of the Commission need to be corrected. This is particularly the case where the Commission is tasked with reform in areas of general social policy, outside its traditional expertise in markets, where its reliance on stakeholders' opinions and assertions (as forms of 'evidence') is even stronger. The Commission should take note of the criticisms directed at law reform based on assertions and anecdotes rather than empirical evidence and research. While we are not opposed to consultation (by any law reform body) as a means of exploring ideas, testing proposals or enhancing stakeholder 'buy in' and the sustainability of reforms, there is a need for caution where this becomes the primary means of evidence-gathering. This has a wider import than just Australia. As explained below, the Commission model is one that other countries have or are looking to emulate. Further, the notion that reforms to law should be rationally based on appropriate and verifiable evidence has been a truism of good government since Jeremy Bentham. ${ }^{5}$ What this article highlights are the different categories of 'evidence' used, or claimed to be used, by law reformers, whether parliamentary parties, governmental department, commissions or even courts, and formulates critical questions that should be asked about the uses of that evidence.

\section{Role and history of the Commission}

This Part provides an overview of the Commission and then documents the rhetoric around the Commission's approach. As will be seen much of this rhetoric contrasts with the actual practices of the Commission as found in the sample of reports analysed.

\section{The Productivity Commission}

The Commission operates under its own Act, the Productivity Commission Act 1998 (Cth) (PC Act). It was described in the second reading speech as 'the government's principal advisory body on all aspects of micro-economic reform' ${ }^{6}$ Its mission is

\footnotetext{
${ }^{3}$ Banks (2010), p 249.

${ }^{4}$ Tranter (2015), p 345.

${ }^{5}$ Judson (1910).

${ }^{6}$ Commonwealth, Parliamentary Debates, House of Representatives, 4 December 1996, p 7720

(Chris Miles, Parliamentary Secretary (Cabinet) to the Prime Minister).
} 
broad and includes promoting 'public policy excellence' and enhancing productivity in Australia. ${ }^{7}$ The functions of the Commission are tied to its role in advising, conducting inquiries and promoting public understanding on matters relating to 'industry, industry development and productivity' (defined to include legislative or administrative action relating thereto). ${ }^{8}$ While inquiries and advice require referral or request from the Minister, research and the promotion of public understanding can be undertaken on the Commission's own initiative. ${ }^{9}$ Publications include draft and final inquiry reports (and issues papers), research reports, newsletters, speeches and annual reports. Not examined in this article are staff, consultancy and visitor papers (unless referenced elsewhere), conference papers and proceedings (unless referenced elsewhere), reports on government service provision (including indigenous expenditure reports), Trade and Assistance Reviews, and activities within autonomous units such as the Australian Government Competitive Neutrality Complaints Office.

The PC Act requires the Commission to have regard to several policy factors in its work. The emphasis of these factors is on the economic wellbeing of Australia. Specific factors include: 'to improve the overall economic performance of the economy through higher productivity', 'to reduce regulation of industry', 'to encourage the development and growth of Australian industries' and 'to facilitate adjustment to structural changes in the economy and the avoidance of social and economic hardships arising from those changes' ${ }^{10}$

In terms of method, the Commission is authorised to use a variety of methods including engaging in consultation, receiving submissions, holding public seminars, conducting workshops and establishing work groups and task forces. ${ }^{11}$ However, the PC Act provides that if a report relies on formal mathematical economic modelling, then the Commission must use at least two different economic models (with explicit assumptions and results) if practicable or else report on the views of an independent reference panel on the modelling. ${ }^{12}$ Peer review is relied on to some extent outside the context of models. Annual reports confirm that drafts of research reports are generally refereed externally, often employing consultants. ${ }^{13}$ There are also some references to external review of staff working papers. ${ }^{14}$ On the other hand, while elements of draft inquiry reports are sometimes peer reviewed (such as for economic modelling), feedback on these reports is generally obtained through the public release of drafts for comment rather than through a separate peer review process. ${ }^{15}$

The Productivity Commission (established in 1998) replaced the old Industry Commission (1990-98), which operated under the Industry Commission Act 1989, also absorbing the Bureau of Industry Economics and the Economic Planning and Advisory Commission. ${ }^{16}$ There was some initial concern that the merger might

\footnotetext{
${ }^{7}$ Banks (2010), p 249.

${ }^{8}$ Productivity Commission Act 1998 (Cth) s 6.

${ }^{9}$ Productivity Commission Act 1998 (Cth) s 6.

${ }^{10}$ Productivity Commission Act 1998(Cth) s 8(1)(a-d).

${ }^{11}$ Productivity Commission Act 1998 (Cth) s 9.

${ }^{12}$ Productivity Commission Act 1998 (Cth) s 8(3).

${ }^{13}$ Productivity Commission (2013-14), pp 31, 77.

${ }^{14}$ Productivity Commission (2012-13), p 117 (concerning staff working paper on trends in the distribution of income in Australia).

${ }^{15}$ Productivity Commission (1997-98), p 52.
} 
result in a loss of research into social issues, ${ }^{17}$ although this was denied at the time and has not proven to be the case. ${ }^{18}$ The Commission continued the ongoing work of the Industry Commission, proceeding with its commenced inquiries, completing its commenced reports, and continuing to hire its staff and perform its contracts. ${ }^{19}$ The Industry Commission itself had grown out of the Industry Assistance Commission, also absorbing the Inter-State Commission and the Business Regulation Review Unit. ${ }^{20}$ The Industry Assistance Commission had in turn replaced the Tariff Board, which had advised the government on questions of assistance for specific industries exposed to competition from imports. ${ }^{21}$ Over the course of this extended history, the functions of the body has changed, due primarily to two policy shifts - from import tariffs to industry assistance as the means of fostering domestic industry, and from consideration of sector-specific needs to a consideration of the interests of the community as a whole. ${ }^{22}$ While there is some level of continuity in the Commission's role, there is also a significant expansion into broader questions of social policy in each incarnation. ${ }^{23}$ Indeed, in its most recent Annual Report, the Commission expresses its hope that 'the Government will increasingly choose to call on the Commission for advice on social reform' given reduced needs for government advice on micro-economic policy. ${ }^{24}$

Like a law reform commission, the Productivity Commission is an independent body with an objective advisory role. ${ }^{25}$ Commissioners are appointed by the Governor General based on the advice of government. ${ }^{26}$ Rather than reporting to the AttorneyGeneral, the Commission reports to the Treasurer (although its predecessors had reported to different ministers at different times). It has had three Chairs over its life - Bill Scales (who had been Chairman of the Industry Commission since 1992), Gary Banks (1998-2012) and Peter Harris (current).

\section{Rhetoric around the Commission's approach}

\section{Government rhetoric}

The history of the Commission and its predecessors is a complicated one, and different political parties have praised or opposed both its existence and philosophy at different points in history. The Commission itself was foreshadowed by John Howard as

\footnotetext{
${ }^{16}$ House of Representatives, Explanatory Memorandum (1996), p 2.

${ }^{17}$ 'Treasury and the IC Take Over the World', Sydney Morning Herald, 29 July 1996. Note that the Industry Commission had conducted some social issue research including in relation to workers' compensation, charitable organisations, government service provision: Productivity Commission (2003), pp 80-83.

${ }^{18}$ 'Energetic, Diverse and Open', Sydney Morning Herald, 6 August 1996, p 14.

${ }^{19}$ Productivity Commission (Repeals, Transitional and Consequential Amendments) Act 1998 (Cth) ss 2, 3, 4.

${ }^{20}$ Productivity Commission (Repeals, Transitional and Consequential Amendments) Act 1998 (Cth) s 4.

${ }^{21}$ Productivity Commission (Repeals, Transitional and Consequential Amendments) Act 1998 (Cth) s 9.

${ }^{22}$ Banks (2012), p 123; Banks (2010), p 13.

${ }^{23}$ Productivity Commission (2003), p 6; Banks (2012), p 141.

${ }^{24}$ Productivity Commission (2013-14), p viii.

${ }^{25}$ Banks (2012), p 121.

${ }^{26}$ Productivity Commission Act 1998 (Cth) s 24.
} 
opposition leader prior to the 1996 election as a vehicle to 'focus national attention on the critical importance of boosting productivity'. ${ }^{27}$ The Bill underwent extensive debate in Parliament, and was eventually passed 17 months after its introduction. The Labor party had made a promise to replace the Commission with a National Development Authority were it to have won government in 1998. However, since then, both Labor and Liberal governments have worked extensively with the Commission.

The Commission keeps track of positive comments on its performance and reputation in its Annual Reports. ${ }^{28}$ There are a number of statements from Liberal and Labor politicians as well as from government agencies reflecting the positive regard in which the Commission is held. Examples include:

- Hon Tony Abbott (Liberal) stated that the Commission 'has done magnificent work on a range of subjects ... there is no better body to look at [childcare and early childhood learning] than the Productivity Commission' ${ }^{29}$

- Hon Jenny Macklin (and Hon Darren Cheeseman) (Labor) described the Commission as 'Australia's leading economic research body';

- Hon Greg Combet (Labor) stated 'I think we need to get as much rigour into that sort of analysis as possible and that's why we are going to the Productivity Commission'; 31

- Hon Craig Emerson (Labor) stated 'The Productivity Commission has a distinguished record in providing impartial, economically rigorous advice and continues to make an indispensable contribution to Australian public policy debate'; 32

- Hon Chris Pearce (Liberal) stated 'The advice provided by the Commission is balanced, objective and thorough'; 33

- Glenn Stevens, Governor of the Reserve Bank of Australia, described the Commission as 'the experts'. 34

\footnotetext{
${ }^{27}$ John Howard, 'A Competitive Australia', Address to the Committee for Melbourne, 18 July 1995, tabled in House of Representatives, 12 September 1996.

${ }^{28}$ In recent years, these have been set out in Appendix B of each Annual Report.

${ }^{29}$ Tony Abbot, 'Transcript of Press Conference, Columbo, Sri Lanka', https://www.pm.gov.au/ media/2013-11-17/press-conference-colombo-sri-lanka, 17 November 2013 cited in Productivity Commission (2013-14), pp 12, 52.

${ }^{30}$ Jenny Macklin and Darren Cheeseman, 'Surf Coast Community Support Tackling Pokie Addiction', 8 December 2011 cited in Productivity Commission (2011-12), p 98.

${ }^{31}$ Greg Combet, 'Announcement of Productivity Commission Study into Emission Reduction Policies in Key Economics', http://www.climatechange.gov.au/ministers/hon-greg-combet-am$\mathrm{mp} /$ transcript/announcement-productivity-commission-study-emission, 15 November 2010, cited in Productivity Commission (2010-11), p 120.

${ }^{32}$ Craig Emerson, 'The Services Industries: Unsung Heroes of Western Australia's Economic Growth Story', speech delivered to the Committee of the Economic Development of Australia, Perth, 14 August 2008, cited in Productivity Commission (2008-09), p 111.

${ }^{33}$ Chris Pearce, 'Statement of Expectations for the Productivity Commission', http://archive. treasury.gov.au/documents/1295/PDF/PC $\% 20$ statement $\% 20$ of $\% 20$ expectations.pdf, 3 May 2007, cited in Productivity Commission (2006-07), p 108.

${ }^{34}$ 'Make the Hard Choices: RBA Boss', The Australian Financial Review (Melbourne), http:// www.afr.com/p/national/make_the_hard_choices_rba_boss_3opR8ucgAJ5LeI9DXTYa4K, 14 June 2012, cited in Productivity Commission (2011-12), p 99.
} 
These comments on the public record seem to establish the Commission as not only enjoying bipartisan support, but having a distinguished place in policy making in Australia. In particular, it is accepted by both sides of politics as 'expert' and 'economically rigorous'.

\section{Self-perception: speeches, annual reports and media releases}

Former Chair of the Commission Gary Banks neatly sums up his view of what the Commission is striving to achieve, and how it goes about its tasks: 'Productivity is central to living standards in [Australia and New Zealand]; reform is central to realising our productivity potential; and advancing both is often crucially dependent on statistical evidence. 35

The centrality of productivity as a goal is unsurprising, and is reiterated in numerous publications, speeches and media releases. There are at least seven references in speeches given by Commission Chairs to Professor Krugman's statement that 'productivity isn't everything, but in the long run it is almost everything'. ${ }^{36}$ Productivity is not seen as an end but rather as the means to achieving high incomes for Australians and hence greater societal wellbeing. ${ }^{37}$ The importance of productivity for welfare is captured by a comment by the current Chair of the Commission that 'productivity growth is the central element in improving our national welfare in future'. ${ }^{38}$ While the Commission is focused on higher living standards as an end and productivity as the means, the Commission claims to evaluate the case for specific programs (such as industry assistance, access to health and education, environmental regulation) on their merits, rather than through an ideological preference for markets. ${ }^{39}$ Nevertheless, it is clear that non-efficient price regulations and 'job-creating' industry assistance are generally frowned upon. ${ }^{40}$

The concept of 'reform' is seen as incorporating a positive element. As in the case of law reform commissions, reform or change for the better is seen as the overall mission. ${ }^{41}$ However, the notion of what better means is coloured by economic rather than socio-legal terminology. Thus, a reform is 'better' if it yields a 'net benefit to the community over time'. ${ }^{42}$

According to former Chair Gary Banks, a cost-benefit approach is crucial in measuring alternatives in order to improve policy. ${ }^{43}$ Reform can (and, according to Banks, ought to) be measured with quantitative tools, in order to demonstrate success and failure, particularly to the broader community. ${ }^{44}$ The difficulty here, as acknowledged in various fora, is the challenge of obtaining suitable data for analysis, particularly given ethical and privacy issues in obtaining data, ${ }^{45}$ necessary reliance on

\footnotetext{
${ }^{35}$ Banks (2012), p 163.

${ }^{36}$ Banks (2012), pp 76, 87, 104, 164; Banks (2010), pp 35, 140; Harris (2013). See Krugman (1992), p 11.

${ }^{37}$ Banks (2012), pp 3, 5, 164.

${ }^{38}$ Harris (2013).

${ }^{39}$ Banks (2010), p 284.

${ }^{40}$ Banks (2012), pp 45, 87.

${ }^{41}$ Banks (2012), pp 106-107.

${ }^{42}$ Banks (2012), p 107.

${ }^{43}$ Banks (2012), p 17; Banks (2010), pp 93-124.

${ }^{44}$ Banks (2012), pp 111-112.

${ }^{45}$ Banks (2012), p 147.
} 
individual perception, ${ }^{46}$ budget cuts in the public sector, ${ }^{47}$ and the alleged 'malaise' in academic economics. ${ }^{48}$

Despite such practical barriers, the importance of evidence as a basis for policy is reiterated throughout speeches and media releases. As noted in the Second Reading speech establishing the Commission, '[s]ound policy development must be based on a full appreciation of the facts'. ${ }^{49}$ The Commission has since been described as being 'at the heart of evidence-based policy making in Australia' ${ }^{50}$ Its 2009-10 Annual Report highlights the importance of evidence-based public policy as opposed to 'sketchy data or quick surveys (or worse, focus groups) that may involve people recalling past behaviours or predicting their responses' ${ }^{51}$ or reliance on 'anecdotal experiences of selected stakeholders'. ${ }^{52}$ Evidence is seen as crucial in both choosing among policy options and obtaining political support for recommendations to achieve implementation. ${ }^{53}$ As Banks states: '[t]here have been some notable examples in Australia of the public policy benefits to be had from quantitative analysis based on relevant and robust statistics'. ${ }^{54}$ In relation to the Commission itself, he states 'it has provided government with a source of well researched advice' with processes that 'ensure that the arguments of vested interests will be subjected to rigorous scrutiny. 55

The emphasis on evidence, including robust quantitative measures, does not mean that stakeholder and public opinion is irrelevant. To the contrary, in its annual reports, the Commission describes transparency and public consultation as a 'central feature' and 'integral to its operation' in that it ensures 'that the Commission's research and policy advice draw on public input and are tested publicly in advance'. ${ }^{56}$ Evidence and consultation are seen as equally important; for instance, Banks reflected on the importance of the 'rigour of research and analysis contained in the Commission's reports' alongside the 'extensive consultations' which allow for proposals to be 'tested through public scrutiny'. ${ }^{57}$ The theme of testing is raised again in an extended discussion of method in the Commission's 2009-10 Annual Report, where it states:

Transparent public processes are important to ensure that necessary judgments by advisers and decision-makers can be adequately scrutinised and tested, particularly by those who will be affected. ${ }^{58}$

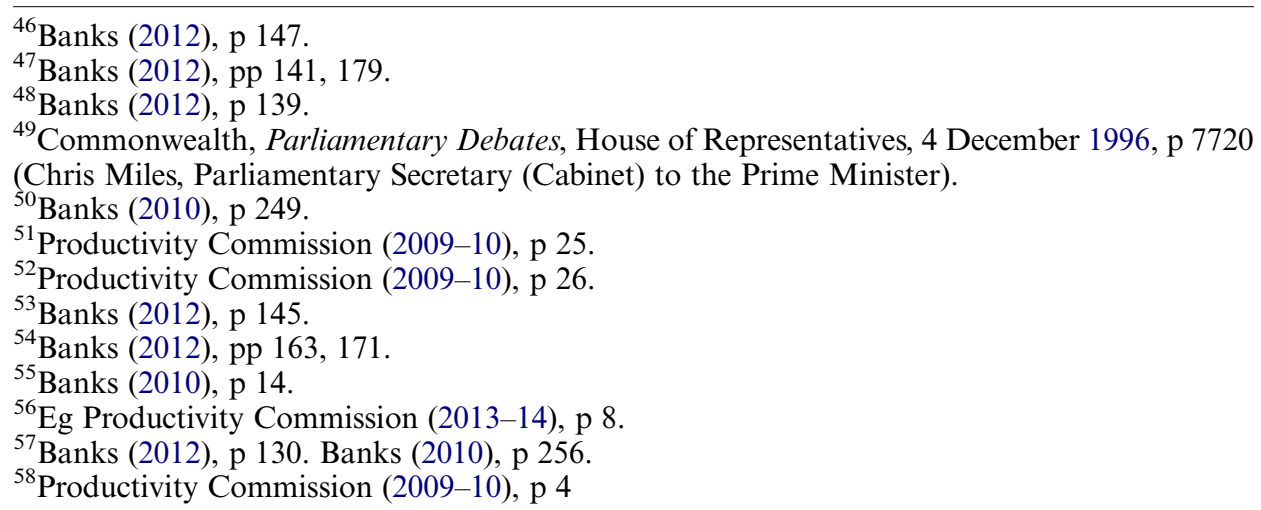


In addition to testing, consultation is said to help ensure that reforms can be sustained, ${ }^{59}$ which requires both 'solid research' and 'effective communication'. ${ }^{60}$ Thus, consultation is seen as important for gauging public reactions ${ }^{61}$ and enhancing awareness and buy-in. ${ }^{62}$

In addition to these goals, consultation is also described as an additional source of 'evidence'. ${ }^{63}$ Early consultation is said to establish a clearer understanding of the 'baseline' situation, the magnitude of problems, the extent of compliance costs, and ensure all relevant options are considered and possible unanticipated consequences uncovered. ${ }^{64}$ Thus, consultation not only facilitates the scrutiny of recommendations but also provides a source of evidence. As the Commission writes:

There is a particular need to ... entrench requirements for public consultation - not only to gather evidence, but also to test competing views and expose draft policy proposals to scrutiny. ${ }^{65}$

Although the PC Act provides for flexibility and a range of working methods, ${ }^{66}$ lip service has certainly been paid to the importance of methodology. ${ }^{67}$ As noted above there are some restrictions in the PC Act itself, particularly where economic models are employed. While outside this field, the Commission can choose the methodology it thinks appropriate, strong views have been expressed on what makes for a good methodology. Former Chair Banks focused on this issue in a speech, where he emphasised the importance of formulating and testing a particular theory, considering the counterfactual of what would happen in the absence of action, quantifying impacts, looking at both direct and indirect effects, being clear about uncertainties, avoiding errors through bias, providing for sensitivity tests and ensuring replicability by third parties. $^{68}$ There is also a strong view that evidence-based methodologies should fit 'broadly within a cost-benefit (or at least cost-effectiveness) framework', which includes accounting for the full range of impacts. ${ }^{69}$ Monetisation of costs and benefits should be the goal, even in relation to social policy in fields such as gambling, consumer protection and animal welfare. ${ }^{70}$ Other important factors, such as independence and the importance of being objective in making assumptions underlying modelling, have also been mentioned. ${ }^{71}$ All of this suggests an emphasis on quantification and objectivity in selecting and generating evidence on which to rest its conclusions.

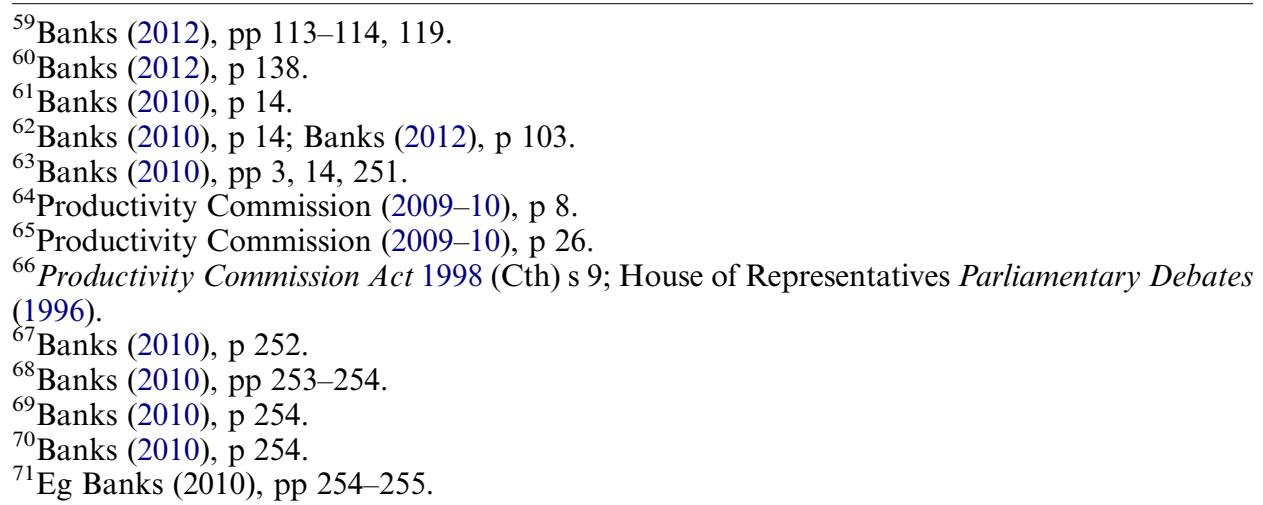




\section{Evaluation}

While there is voluminous literature by those involved in the Productivity Commission, mostly in the form of speeches by its Chair as well as its own self-written history, ${ }^{72}$ very little has been written externally about its general methods and approach. Most of what does appear in the literature is specific to a particular inquiry, discussing particular recommendations for the purposes of either applause or critique. In some cases, critique of the Commission extends to its approach or to methodologies employed. For instance, it has been argued that 'the real significance of [a Commission report] lies in the fact that it provides a veneer of legitimacy for a neoliberal political agenda ${ }^{, 73}$ and that the Commission employs 'dubious analytical assessment' with 'anecdotal references ... no substitute for a thorough analysis'. ${ }^{74}$ More specific objections have been taken by a former Commissioner, who suggested that implementation costs were in one case ignored leading to over-estimation of benefits. ${ }^{75}$ There is one critique of the economic model employed exclusively at an earlier point in the Commission's history, ${ }^{76}$ although that seems to have been rectified by statutory requirements to use multiple models or have these evaluated. However, most critiques relate to specific publications or recommendations rather than broader questions.

Internationally, the Commission has an excellent reputation. The OECD has lavishly praised the Commission as 'a major source of innovative policy advice and analysis' and a 'model for institutionalising evidence-based policy-making' with 'a strong analytical tradition' and 'excellent analytic work'. ${ }^{77}$ The OECD has also suggested that other countries can learn from Australia's experience with the Commission, particularly Mexico and Germany. ${ }^{78}$ Indeed, other countries have themselves looked to the Australian Productivity Commission as a model to be followed in their own jurisdictions. For instance, Lianne Dalziel reportedly stated as the New Zealand Minister for Commerce that if she could turn one Australian agency into a trans-Tasman institution, it would be the Commission. ${ }^{79}$ New Zealand did ultimately create its own Productivity Commission in 2010. Denmark and Norway have also created productivity commissions. ${ }^{80}$ Other countries have made inquiries with a view to possibly establishing a similar organisation, ${ }^{81}$ and the Indian Council for Research and International

\footnotetext{
${ }^{72}$ Productivity Commission (2003).

${ }^{73}$ Purse et al (2004b).

${ }^{74}$ Purse et al (2004a).

${ }^{75}$ Sloan (2011), p 35.

${ }^{76}$ Manning (1998) (critiquing the Commission's use of the Orani economic model).

${ }^{77}$ OECD (2010), pp 86-87, 177.

${ }^{78}$ OECD (2013), p 51 (recommendation for Mexico to create 'a high-level inter-agency body focused on productivity similar to Australia's Productivity Commission'); OECD (2011), p 20 (recommendation for Germany to establish 'an advisory body tasked with reviewing regulation and other issues - similar to the Australian Productivity Commission').

${ }^{79}$ Brenchley (2008), p 26; Productivity Commission (2005-06), p 96.

${ }^{80}$ International Monetary Fund (2014), pp 14, 21-22.

${ }^{81}$ Sloan (2011), p 36; The Scotsman, 'Former Auditor General Calls for Public Services Watchdog' http://www.scotsman.com/news/health/former-auditor-general-calls-for-public-serviceswatchdog-1-2763951, 29 January 2013 (former Auditor-General of Scotland calls for 'Australian-style productivity commission'); Waller (2012) (recommendation for Taiwan 'to establish an independent advisory body in Taiwan to promote structural reforms to enhance competition and productivity').
} 
Economic Relations called for the establishment of a Productivity Commission there. ${ }^{82}$ Even without emulation, there has been praise. Chinese government advisers have reportedly praised the Commission's approach as 'scientific policy making, ${ }^{83}$ The Commission has also been praised in business circles, with the Business Council of Australia chief executive describing its 'excellent work, high standard of research and professionalism'. ${ }^{84}$

In summary, the Commission is nationally and internationally respected as a leading source of policy advice to the Commonwealth. This esteem appears linked to the quality of its reports, the reliance on quantitative evidence, and its use of consultation. Given the rhetoric associated with the Commission, our expectation was that Commission reports would have a different citation profile compared to law reform commission reports, with greater reliance on the quantitative and empirical data. While we expected the Commission to rely on consultation and stakeholder submissions, we expected such use to relate primarily to the testing of findings (empirically and politically), with only secondary use as evidence. It is this hypothesis that we set out to test.

\section{Method}

Having established our hypothesis, we discovered that there had been no research analysing the Commission's approach across different inquiries. Given the significance of Commission reports in law and policy reform, and reflecting the Commission's own rhetoric around quantitative measures, we wanted to utilise an empirical instrument to test our hypothesis. In particular, we were curious as to the extent to which the recommendations within Commission reports could be linked back to findings from quantitative research, as opposed to stakeholder viewpoints and opinions.

\section{Methodologies employed in previous studies}

In undertaking this task, we looked to methodologies employed in previous studies analysing reports of reform commissions. Angela Melville undertook a parallel comparative analysis of a report from the New Zealand Law Reform Commission and the then Law Commission of Canada. ${ }^{85}$ Her concern was to 'highlight the differing ways in which the commissions put their principles into practice'. She found that the New Zealand Law Reform Commission report was legalistic in style. It was not transparent in its methods, nor did it seem to put much weight on information derived from community consultations. ${ }^{86}$ In contrast, the Law Commission of Canada's report revealed an interdisciplinary approach that was reflective of its publically stated methods and 'included views other than just legal perspectives'. ${ }^{87}$ What is significant from Melville's

\footnotetext{
${ }^{82}$ Hindustan Times (Washington), 'Indo-US Study Finds India's Growth Model 'Flawed", http://www.hindustantimes.com/business-news/indo-us-study-finds-india-s-growth-modelflawed/article1-1173342.aspx, 15 January 2014.

${ }^{83}$ Brenchley (2008), p 79.

${ }^{84}$ Brenchley (2008), p 79.

${ }^{85}$ Melville (2007). The Law Reform Commission of Canada was unfunded in 2006. See MacDonald (2008).

${ }^{86}$ Melville (2007), p 161.

${ }^{87}$ Melville (2007), p 161.
} 
limited study is that she did not rely upon statements and rhetoric from the commissions concerning how they approached law reform but reconstituted their approach from their reports. A criticism of Melville's study is that she does not disclose her own methodologies through which her process of reconstituting was conducted. She describes her approach simply as 'comparing' without any explanation of how this comparison was undertaken. ${ }^{88}$

An alternative approach to studying commission reports has been recently undertaken by Kieran Tranter who applied the practice of citation analysis to a sample of ALRC reports. ${ }^{89}$ Citation analysis has been used to examine the citation practices of the judiciary in law reports ${ }^{90}$ and of legal academics in law journals. ${ }^{91}$ In Australia, Russell Smyth has comprehensively applied the method to determine the citation patterns of the Australian superior courts. ${ }^{92}$ Citation analysis has also been applied to samples of Australian law journals. ${ }^{93}$ Tranter suggests that citation analysis is a meaningful method through which to analysis law reform commission reports as the practice of citing 'tells a reader that the proposition that is accompanied by a citation has authority, not just because the author is saying it, but that others have said it' ${ }^{94} \mathrm{He}$ suggests that "citation analysis can be a form of archaeology whereby the processes of shaping a given text can be uncovered through examining the citations' ${ }^{95}$

However, there are limitations to the citation analysis approach. The focus is on counting and categorising citations. Tranter was able to document that, over the past 20 years, the ALRC has referred to 120310 sources in its citations comprising submissions (46 per cent), cases or legislation ( 25 per cent), material produced by government (14 per cent) and books and journals ( 6 per cent). ${ }^{96}$ Tranter concluded that the high citation of submissions is evidence that substantiates the ALRC's claim that it undertakes law reform through a community consultative approach. ${ }^{97}$ However, what Tranter's study did not consider was how individual citations were used. It involved extracting and then counting and cataloguing the citations out of context. While 46 per cent of the ALRC citations have been to submissions, it might be - although unlikely - that it only cites from submissions when it disagrees with the submission and its actual recommendations are derived from government

\footnotetext{
${ }^{88}$ Melville (2007), p 156.

${ }^{89}$ Tranter (2015).

${ }^{90}$ Merryman (1978); Friedman et al. (1981); Johnston (1985); Harris (1985); Schriek (1991); Sirico and Drew (1991); Manz (1995); McCormick and Praskach (1996); McCormick (1996a); McCormick (1996b); Kopf (1997); Manz (2001); Beaird (2002); Cosanici and Long (2005).

${ }^{91}$ Maru (1976); Shapiro (1985); Shapiro (1991); Shapiro (1995); Landes and Posner (1995); George and Guthrie (1999).

${ }^{92}$ Smyth (1999a); Smyth (1999b); Smyth (1999c); Smyth (1999d); Smyth (2000a); Smyth (2000b); Smyth (2001a); Symyth (2001b); Smyth (2002); Fausten et al. (2007); Smyth (2007); Fausten and Smyth (2008); Nielsen and Smyth (2008); Smyth (2008a); Smyth (2008b); Smyth (2009a); Smyth (2009b).

${ }^{93}$ Ramsay and Stapledon (1997); Voon and Mitchell (1998); Smyth (2012).

${ }^{94}$ Tranter (2015), pp 326-327; see also Batagol and Castan (2012).

${ }^{95}$ Tranter (2015), p 327.

${ }^{96}$ Nine per cent were to newspapers, material produced by NGOs and other unclassified sources: Tranter (2015), p 337.

${ }^{97}$ Tranter (2015), p 345. On the ALRC's community consultative approach, see Kirby (1983), pp 56-61; Opeskin (2002); Weisbrot (2005), p 32.
} 
or academic sources. A citation analysis approach cannot address this concern as it does not connect conclusions and recommendations to the part of the text that synthesised or justified the conclusion and recommendation. As such, it cannot identify the sources of authority that were used in those particular blocks of text. While citation analysis develops document-wide metrics concerning what was cited, it is not sufficiently detailed and discerning to analyse the impact of particular sources.

Moving beyond prior studies of commission reports, we considered the ethnographic approach of Bruno Latour. In his ethnography of the French Conseil d'Etat, Latour became intrigued at the textual process whereby the commissioners constructed their final judgments from 'stacks' of other texts and successive drafts. ${ }^{98}$ Latour's suggestion - that documents, particularly law and government texts - have on their final versions the traces of the earlier texts through which they were formed, seems to fill a gap between Melville's 'comparing' and Tranter's citation metrics. What Latour suggests is that final documents can be stripped away to show what was relied upon. While the Conseil d'Etat is not a reform commission but rather forms final appellant jurisdiction of the French administrative law regime, ${ }^{99}$ the same observation applies. The statutory mandate to report to Government is usually understood by reform commissions to require a series of numbered recommendations. These are often used by reform commissions to document their successes that is reporting that the Government has legislated or otherwise adopted identifiable and countable numbers of recommendations. ${ }^{100}$ In short, the success or failure of a reform commission report is often considered to be, at least in part, the number of recommendations taken up by government. ${ }^{101}$ This means that recommendations are the clear end-points of a report. Reports are written to frame, explain and justify the recommendations. For the study of reform commissions, recommendations present as the place to start.

This study does just this. Its method started with the recommendations and worked back through the reports to the sections where specific recommendations were discussed. It then identified and recorded the sources used by the Commission to support the recommendation. In this way the issue of impact, that was not answerable by a straight citation analysis, was directly addressed. The following section provides a detailed description of the methodology employed.

\section{Methodology employed in current study}

For the purpose of this study, we selected a sample of six inquiry reports and one research report. The inquiry reports were Compulsory Licensing of Patents (2013), ${ }^{102}$ Default Superannuation Funds in Modern Awards (2012), ${ }^{103}$ Australia's Anti-Dumping and Countervailing System (2009), ${ }^{104}$ the two volume Caring for

\footnotetext{
${ }^{98}$ Latour (2010), pp 86-87.

${ }^{99}$ Latour (2010), pp 111-114.

${ }^{100} \mathrm{Eg}$ the ALRC's statements about implementation activities for final reports in Appendix F and $\mathrm{G}$ of its recent annual reports. Australian Law Reform Commission (2012-13), pp 126143; Australian Law Reform Commission (2011-12), pp 147-169.

${ }^{101}$ Opeskin (2005), pp 201, 202, 216.

${ }^{102}$ Productivity Commission (2013a).

${ }^{103}$ Productivity Commission (2012).

${ }^{104}$ Productivity Commission (2009).
} 
Older Australians (2011), ${ }^{105}$ the two volume Electricity Network Regulatory Frameworks $(2013)^{106}$ and the two volume Disability Care and Support (2011). ${ }^{107}$ The research report we selected was Major Projects Development Assessment Processes (2013). ${ }^{108}$ This sample was selected based on a series of considerations. First, we focused on inquiry reports because these were the 'final' reports of an inquiry, representing the Commission's full and concluding advice to government. One research report was included to provide a contrast. Second, recent reports were chosen. Third, the topics of the reports were selected based on two considerations. The first was that the report provided detailed recommendations directed to legislative and policy changes. The second was that the topic was not 'economic' in a pure sense, but had a wider 'social focus'. Informing this last consideration was the perspective of whether we thought that the topic could have been inquired into by the ALRC. We acknowledge that this was a highly subjective assessment but justified it on the basis that it provided a sample that could allow us to meaningfully compare our findings from the sample of the approach of the Commission to seemingly analogous reform commissions, most particularly the ALRC.

We conducted a detailed analysis of each Productivity Commission report. The focus of our study was on evidence and submissions that had an 'impact' on the recommendations made by the Commission. This focus informed the process we followed in analysing each of the reports.

\section{Outline of methodology}

The analytical methodology employed in this study comprised four main steps. In the first step, we would locate and print out the list of recommendations made by the Commission. The complete list of recommendations is often found after the overview at the start of the reports.

The Commission groups together recommendations on the same subject in individual chapters of its reports. Each chapter can have from 1 to over 15 recommendations. We would read each of the chapters containing recommendations. This led to the second step in our analytical methodology, which was to identify pieces of evidence that the Commission referred to as framing, explaining or justifying the particular recommendations of that chapter. By 'evidence' in this context, we mean written submissions made by participants in the inquiry, oral submissions made by participants at the public hearings and other sources (such as academic articles and governmental reports) that the Commission referred to in its reports. Each piece of evidence that we identified as supporting a particular recommendation would be highlighted and then recorded. We did not record pieces of evidence that were discussed but subsequently refuted by the Commission, as the scope of our study was not designed to capture this type of data. It was often quite easy to determine whether the Commission relied on or refuted a piece of evidence, as often evidence from participants in the inquiry was listed in boxes in the reports under headings which indicated whether the Commission accepted or rejected the evidence. However, this was not a universal

\footnotetext{
${ }^{105}$ Productivity Commission (2011a).

${ }^{106}$ Productivity Commission (2013b).

${ }^{107}$ Productivity Commission (2011b).

${ }^{108}$ Productivity Commission (2013c).
} 
feature of the reports, and for many chapters it was only possible to determine which evidence the Commission was relying on by carefully reading the chapter and looking at the evidence in the context of the Commission's commentary.

After we had analysed each chapter of a report, highlighting and recording each piece of evidence that the Commission had relied upon in making the individual recommendations, the third step was to locate and identify the source of this evidence. This involved tracing the evidence back to its original source. We would start by locating the original text from which the Commission had drawn the evidence. In most cases, this would be a written submission from one of the inquiry participants. However, sometimes the evidence was drawn from academic articles or government reports, in which case we would locate these sources. We would then identify the section of the submission, article or report where the evidence quoted or referred to by the Commission was located. This was often quite simple, as the Commission often gives a page number identifying where in the source the evidence is located.

Once we had located the piece of evidence in the source, the fourth step was to categorise this evidence. The first type of categorisation was to determine whether the source of the evidence referred to by the Commission was the primary source, or whether the evidence relied on some secondary source. If it was the latter, we would continue the tracing process to find the original source of the evidence. For the purpose of this article, primary sources are those sources that were directly referred to by the Commission in making the recommendations in their reports. Secondary sources are those sources that were referred to by the primary source. For example, in Compulsory Licensing of Patents, the Commission noted that: 'the Centre for Law and Genetics observed: "our empirical evidence indicates that those who would consider applying for a compulsory licence perceive that the financial cost is prohibitively high". ${ }^{109}$ In this example, the Centre for Law and Genetics' written submission would be categorised as the primary source, and the empirical evidence on which they based their submission would be categorised as the secondary source. The second type of classification was to determine the category of source. There were three main categories: submissions (written or oral), journal articles or reports. The third type of categorisation was to determine the nature of the evidence. We developed six categories: namely, mere assertions, legal or logical arguments, empirical evidence, economic arguments, scientific arguments and personal experience. We would read the cited evidence in the context of its original source and classify it, recording the result. The following section provides a more detailed description of these categories.

\section{Categorisation of evidence}

The mere assertion category encompassed statements from participants or other bodies that were not supported by any type of argument or evidence. Many of the statements that fell within this category were to the effect that the participant supported a particular recommendation. However, others were simply unsupported statements. For example, in Default Superannuation Funds in Modern Awards, the Commission relied on an assertion of the Australian Institute of Superannuation

${ }^{109}$ Productivity Commission (2013a), p 117. 
Trustees that the current system by which default superannuation funds are selected for awards 'can appear opaque'.110

In contrast, the argument category included statements made by participants that were supported by either logical or legal arguments that were explicitly explained. For example, in Compulsory Licensing of Patents, the Commission relied on the legal argument of Charles Lawson that s 135 of the Patents Act 1990 (Cth) creates uncertainty because there is no definition of the terms 'reasonable period' and 'reasonable terms and conditions'. ${ }^{111}$ An example of a logical argument relied on by the Commission was provided by the Independent Commission Against Corruption in Major Project Development Assessment Processes that

a transparent planning system requires the provision of publicly available information so that members of the public understand what is being proposed, why decisions have been made, what has influenced those decisions, and the processes involved in making a decision. ${ }^{112}$

The empirical evidence category encompassed statements supported by statistical evidence, which could have been derived from interviews, surveys or statistical analysis thereof. For example, in Australia's Anti-dumping and Countervailing System, the Commission relied on empirical evidence provided by the Australian Customs and Border Protection Service, which demonstrated that the vast majority of its investigations required extensions in time. ${ }^{113}$

The economic argument category included statements supported by economic theories or rhetoric. For example, in Electricity Network Regulatory Frameworks, the Commission relied on the economic argument of the Australian Energy Market Operator, that 'effective competition has the capacity to reduce market power and overcome information asymmetry problems'. ${ }^{114}$

The scientific argument category was intended to include any statements based on scientific analysis or evidence. However, in the reports examined in this study, the Commission did not rely on any such statements in making its recommendations.

The personal experience category encompassed statements made by participants that were based solely on their personal experiences. For example, in Caring for Older Australians the Commission relied on a submission from Clare Dewan that she had 'observed the results of having little or no quality control processes in place for the Registered Training Organisations'. ${ }^{115}$ These differed from the empirical evidence category in comprising a single anecdote or summarising a single person's experience, rather than an attempt to capture (quantitatively or qualitatively) a broader picture.

${ }^{110}$ Australian Institute of Superannuation Trustees (2012) quoted in Productivity Commission (2012), p 154.

${ }^{111}$ Lawson (2008), p 132, quoted in Productivity Commission (2013a), p 147.

${ }^{112}$ Independent Commission Against Corruption (2012) quoted in Productivity Commission (2012), p 126.

${ }^{113}$ Australian Customs and Border Protection Service (2009) quoted in Productivity Commission (2009), p 141.

${ }^{114}$ Australian Energy Market Operator (2013) quoted in Productivity Commission (2013b), p 617.

${ }^{115}$ Clare Dewan and Associates (2012) quoted in Productivity Commission (2011a), p 377. 


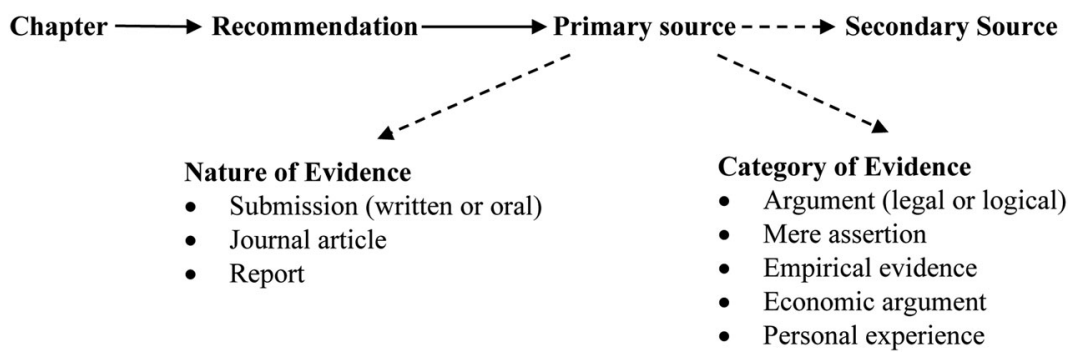

Figure 1. The analytical methodology employed in analysing Commission reports.

\section{Example of the application of the methodology}

The analytical methodology described above is illustrated in Figure 1 which provides a schematic flow-diagram of the process of analysis.

The application of our analytical methodology can also be illustrated by way of an example of an analysis of one of the recommendations from Caring for Older Australians. In this report, recommendation 17.2 stated that:

The Australian Government should negotiate with providers of care services to existing care recipients to harmonise care subsidies and other arrangements. It should reach an agreement within five years that would have the effect of removing grandfathering arrangements for existing and new places while protecting existing recipients of care from changes that would impose a new cost upon them. ${ }^{116}$

We began with Chapter 17, as this was the chapter in which the recommendation was made. By closely reading the chapter, we were able to identify a number of pieces of evidence that the Commission relied upon in making this recommendation. For example, we identified that the Commission relied on a piece of evidence put forward by Medicare Australia, after reading the following passage from the report:

There is already a legacy of grandfathering, particularly in relation to fee schedules, which adds to the complexity of the sector. Indeed, there are multiple levels of Government subsidies and co-contributions based on when a person entered care. As Medicare Australia said: 'Grandfathering existing rules means increased complexity for both providers and Medicare Australia, with multiple sets of rules running in parallel in order to determine payments. ${ }^{117}$

Having identified that the Commission was relying on this piece of evidence in making recommendation 17.2, we proceeded with the third step of our analysis, which was to analyse the nature of this evidence. In order to do this, we located the source of this evidence - the written submission that Medicare Australia made to the inquiry. Having located the source, we proceeded with the fourth step of our analysis, being the categorisation of the evidence. By examining the submission, which made no reference to another supporting source, we were able to determine that the evidence was only based on a primary supporting source - namely Medicare Australia's written

\footnotetext{
${ }^{116}$ Clare Dewan and Associates (2012) quoted in Productivity Commission (2011a), p 489.

${ }^{117}$ Clare Dewan and Associates (2012) quoted in Productivity Commission (2011a), pp 487-488.
} 
submission. By reading this piece of evidence in the context of the written submission, we were also able to categorise the evidence as being based on a logical or legal argument.

By employing the analytical methodology described above, we were able to identify and categorise pieces of evidence that the Commission directly relied on in framing, explaining or justifying its recommendations. In this way, our analysis focused on the 'impact' of the evidence, which will be highly instructive in determining trends in the type of evidence that is persuasive to the Commission.

\section{Findings}

In this part, we set out the aggregate findings of our analysis of the sample. ${ }^{118}$

The aggregated data provide an overall summary from the sample of the trends in the evidence relied upon by the Commission in making recommendations. As Figure 2 shows, our data suggest that the vast majority of evidence relied upon by the Commission can only be traced back to one source, with only six per cent of evidence being supported by a secondary supporting source. Further, Figure 3 demonstrates that the majority of these primary sources were submissions ( 83 per cent), with a smaller number reports (12 per cent) and journal articles ( 5 per cent). Figure 4 demonstrates that the majority of evidence relied upon by the Commission in its reports is based on logical or legal arguments (58 per cent), with a large number being based on assertions (23 per cent), and smaller numbers being based on empirical evidence ( 9 per cent), economic arguments (5 per cent) and personal experience ( 5 per cent).

\section{Discussion}

In this part, we discuss the findings of our study. First we consider whether the findings suggest that the Commission has different approaches depending whether the topic is more market-based or more social policy in orientation. Second, we compare our findings to the recent study of the ALRC. Third, we address the over-arching finding as it relates to our hypothesis whether the Commission's approach is 'evidence and consultation' or 'evidence as consultation'?

\section{Inquiry reports suited to the Commission}

As discussed above, the Commission's own rhetoric emphasises the importance of the empirical, rigorous, quantitative analysis in proposing and evaluating recommendations in its inquiries. According to former Chair Banks in particular, costs and benefits of proposed reforms need to be quantified and ideally monetised. ${ }^{119}$ For this reason, our results are surprising, as across all the reports that we analysed the majority of the evidence that was relied upon by the Commission in making its recommendations were based on logical or legal arguments. The second largest category of evidence relied upon by the Commission was the mere assertion category. Indeed, the empirical evidence category was generally only the third largest category of evidence relied upon by the Commission in making recommendations.

\footnotetext{
${ }^{118} \mathrm{~A}$ breakdown of our data and findings for each report is available from the authors.

${ }^{119}$ See above text accompanying notes $35-71$.
} 


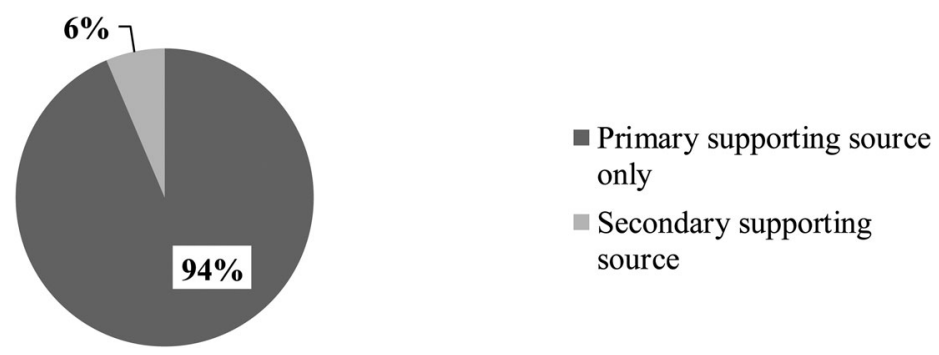

Figure 2. Aggregate: evidence that was supported by primary and/or secondary supporting source(s).

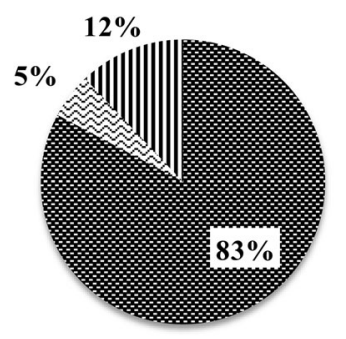

\author{
c Submissions (written and oral) \\ $\approx$ Journal articles \\ II Reports (government and \\ other)
}

Figure 3. Aggregate: category of sources relied upon by the Commission.

There were certain reports where the empirical evidence category accounted for a significant proportion of the evidence relied upon by the Commission, notably in Compulsory Licensing of Patents, Default Superannuation Funds, Electricity Network Regulatory Frameworks and Major Projects. However, there were other reports where only a small proportion of empirical evidence was relied on, such as Caring for Older Australians and Disability Care and Support. Instead, in these last two reports the Commission utilised a large amount of evidence from the legal/logical arguments, mere assertion and personal experience categories. In both these reports, the Commission relied heavily on the submissions from the participants in its final reports.

From these results, it is our suggestion that the Commission is better able to employ quantified, empirical evidence in inquiries where the focus is on marketbased issues - such as compulsory licensing, superannuation fund regulation and electricity network regulation. When inquiries focused on social issues - such as disability and aged care - the Commission placed less reliance on such evidence. It should be noted that our results in this regard are by no means conclusive, as they are limited by the small sample size of reports that we analysed. However, we believe that these results disclose a trend, and it would be interesting to test this further in future studies.

The Commission itself does not seem to be aware of this distinction in the type of evidence on which it relies for different types of inquiries. As noted above, former Chair Banks was of the view that quantified and monetised costs and benefits should be the basis for decision making even in relation to social policy in fields 


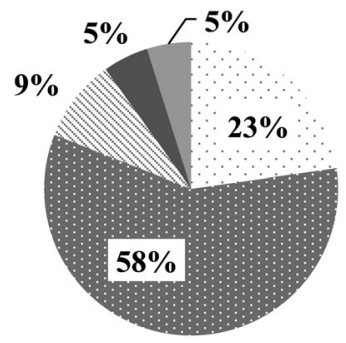

Mere assertion

Argument (logical/legal)

Empirical evidence

- Economic argument

- Personal experience

Figure 4. Aggregate: type of evidence relied upon in making recommendations.

such as gambling, consumer protection and animal welfare. ${ }^{120}$ We were not able to find any statement in speeches or annual reports of the Commission that ran counter to this view that social policy can be evaluated on similar terms to market policy. While the Commission has been noted that data are sometimes hard to procure, our results suggest that something other than a general difficulty in obtaining quality data is at play. In particular, it would seem that some kinds of issues are less susceptible to an economic approach based on analysis of quantitative data than others. Where the Commission is asked to consider social issues outside its traditional areas of expertise, it necessarily relies more heavily on assertions made by stakeholders and anecdotes of individual experiences.

Interestingly, the distinction between economic/market and social issues would seem to be more important in predicting the type of evidence on which the Commission will rely than the form of inquiry. As explained at the outset, we looked at a single research report, comparing this to the inquiry reports. The research report was identified as having 69 per cent of the evidence used based on logical/legal arguments, 15 per cent on empirical evidence, 14 per cent assertions and 2 per cent economic arguments. ${ }^{121}$ This compares to the aggregate results of 58 per cent logical/legal arguments, 23 per cent assertions, 9 per cent empirical evidence, 5 per cent economic arguments and 5 per cent personal experience. ${ }^{122}$ While this is not sufficient evidence base for a final conclusion, it does suggest that the distinction between economic policy and social policy is more worthy of further exploration, at least initially, as a basis for understanding the limitations of the Commission's approach. Where the Commission is investigating and recommending around social issues, it relies more on assertions and anecdotes made by stakeholders. This immediately raises a question of how the Commission's reports in these latter areas are different to the reports produced by other reform commissions.

\section{Comparison to the ALRC}

Tranter's recent citation analysis of a sample of the ALRC provides a way of comparing the findings about the Commission in this article to an institution that has long advised the Commonwealth on law reform, often in areas that can be seen as more

\footnotetext{
${ }^{120}$ Banks (2010), p 254.

${ }^{121}$ See above Figure 4.

${ }^{122}$ See above Figure 4.
} 
broadly social policy in focus. ${ }^{123}$ As outlined above Tranter found that in his sample of the final reports by the ALRC from 1991 to 2012 that 46 per cent of citations were to submissions made during the course of the inquiry, 25 per cent to cases or legislation, 14 per cent to material produced by government and 6 per cent to books and academic journals. ${ }^{124}$ This is broadly similar to the aggregate findings in this article that the Commission's recommendations were based on submission ( 83 per cent), reports (12 per cent) and journal articles (5 per cent). ${ }^{125}$ Indeed, the Commission appears to rely to a greater degree than the ALRC on submissions. Also similar was the fact that both commissions seem to have recourse to academic material such a journal articles in around 5 per cent of references.

This comparison is highly inaccurate. As has been identified above, the differences in the methods between Tranter's study and the study in this article are quite fundamental. Tranter counted and coded all citations; ${ }^{126}$ there was none of the more finely grained identification of impact of specific citations as was conducted in this study. There remains to be done a study to apply the method used in this study to a sample of ALRC reports to look at sources and evidence that supported recommendations, and there also remains to be done a study that applies a citation analysis to a sample of the Commission's reports. However, as an impression what is striking between the findings of both studies is the prominence (in Tranter's study) and impact (in this study) of submissions. It seems that, for both commissions, making submissions matters.

This opens to a particular issue with submissions. As noted the Commission's rhetoric concerning submissions has an ambiguity about it. At the forefront has been the affirmation of quantifiable data as the best evidence on which to base recommendations for reform. However, parallel has been a concern with ensuring consultation. ${ }^{127}$ This has come in two guises. First as a notion of public scrutiny; of ensuring analysis and preliminary recommendations by the Commission are seen as appropriate and reasonable to stakeholders. Here consultation is considered as a next stage that affirms or refines recommendations initially based on 'evidence'. This can be summarised as the 'evidence and consultation' approach. The second is 'consultation as evidence' where the submissions are data to be added to a mix of data that includes quantifiable data and secondary literature to be used directly by the Commission in the formulation of recommendations. ${ }^{128}$

This study shows that when the Commission synthesises a recommendation, 83 per cent of the citations within that text are to submissions. This strongly suggests that the Commission's dominant approach is to use consultation as evidence. In addition, when we went further and examined the submissions, we found that the critical point that the Commission relied upon was drawn 58 per cent on logical/legal

\footnotetext{
${ }^{123}$ See, for example, Australian Law Reform Commission (1996); Australian Law Reform Commission and Australian Health Ethics Committee of the National Health and Medical Research Council (2003); Australian Law Reform Commission (2008); Australian Law Reform Commission and New South Wales Law Reform Commission (2010).

${ }^{124}$ Nine per cent were to newspapers, material produced by NGOs and other unclassified sources: Tranter (2015), p 337.

${ }^{125}$ See Figure 3.

${ }^{126}$ Tranter (2015), p 335.

${ }^{127}$ See above text accompanying n 56.

${ }^{128}$ See above text accompanying n 63 and n 65 .
} 
arguments, 23 per cent from mere assertions, 9 per cent on empirical evidence, 5 per cent on economic arguments and 5 per cent from personal experiences. ${ }^{129}$ While the Commission's rhetoric suggests consultation is supplementary to evidence, our findings show that, when it comes to recommendations, the overwhelming practice of the Commission has been to utilise consultations as evidence.

\section{Evidence and consultation or evidence as consultation}

The process of consultation, receiving submissions and then the incorporating of those submissions into a final report, has become the standard and expected way that reform commissions operate in Australia. ${ }^{130}$ It is the approach that the ALRC in its annual reports claims it uses ${ }^{131}$ and it has long be advocated within the literature on institutional law reform. ${ }^{132}$

Regina Graycar has been a lone voice in questioning the appropriateness of submissions in the context of reform. ${ }^{133}$ Her argument favours a strong version of the "evidence and consultation' approach. Her focus is the changes that introduced 'shared care' arrangements into Australian family law. ${ }^{134}$ She identified that these reforms came about because of the successful advocacy by 'Father's Rights' groups. In particular, Graycar found that these groups undermined, in the minds of lawmakers, existing Australian academic research into domestic violence, poverty rates of single mothers and the effects of separation on the welfare of children, by emphasising the suffering of non-care fathers. ${ }^{135}$ What was significant for Graycar about the campaigns were that they were not based on empirical evidence or reliable studies, rather anecdotal statements and stories. The highlight for Graycar was the argument used to undermine the very clear statistical evidence concerning women and children as victims of domestic violence perpetrated by men in Australia. It was claimed that men suffer domestic violence at the hands of women because one advocate had gone on the public record claiming that his ex-partner had once 'chucked a frozen chook' at him. ${ }^{136}$

Graycar uses this provocative image of reform by frozen chook to problematise the use of consultation and submissions by reform commissions. She argues that reliance on submissions could distort the investigation process and ultimately corrupt the good intentions of the reform commission. There are two dimensions to this. The first is that undertaking consultation and asking for submissions privileges sectors of the community and economy with the skills and resources to respond. ${ }^{137}$ This is of a particular concern in the social policy reform area where the voices of the very people whose

\footnotetext{
${ }^{129}$ This data were for all the arguments across the sources cited by the Commission. However, with such a large percentage ( 83 per cent) as submissions, it is reasonable to assume that the percentages of argument codings for submissions tracks closely the overall figures.

${ }^{130}$ Barnett (2011), pp 172-181; Davis (2005), p 148.

${ }^{131}$ Australian Law Reform Commission (2013-14), p 17.

${ }^{132}$ Kirby (1983), pp 56-61; Sackville (1983), pp 223-240, 226; Opeskin (2002); Weisbrot (2005), pp 18-39, 32.

${ }^{133}$ Graycar (2000); Graycar (2012); Graycar (2005); Graycar and Morgan (2005).

${ }^{134}$ Graycar (2000), p 745; Graycar and Morgan (2005), pp 393, 416.

${ }^{135}$ Graycar (2000), pp 737-746; Graycar (2012), p 263.

${ }^{136} \mathrm{~A}$ 'chook' is Australian colloquial for chicken. Graycar (2000), p 745; Graycar and Morgan (2005), pp 393, 416.

${ }^{137}$ Graycar and Morgan (2005), pp 406-407.
} 
welfare and wellbeing are being investigated could be marginalised. ${ }^{138}$ The second is that submissions are usually sectorial and often anecdotal.

Michael Saks has also written about the use of anecdotal statements within the context of advocacy of law reform. His focus was on the positioning and calls for reform to US tort litigation. ${ }^{139} \mathrm{He}$ identified a significant use of factoids, 'statements that sound like facts, that seem as though they are conveying some information, but that on examination turn out to be false or meaningless'. ${ }^{140}$ Submissions, as we have identified, tend to be full of factoids as defined by Saks, ${ }^{141}$ bald assertions about the world that bolster the submitter's position. In this submissions can be seen as akin to 'submissions' within an adjudicative context and as such involve the presentation of an argument and advocacy for a particular outcome. There are no standards for what is in a submission nor any independent check on the facts and evidence presented beyond the reform commission's own judgment of reliability and probity. For Graycar and Saks, the danger of factoid laden submissions is that serious and fundamental issues that need to inform a reform process, like hard data on the incidents and nature of domestic violence for family law reform, or empirical evidence on actual payout amounts in tort ligation, become swamped by inflammatory statements about projectile domestic fowl ${ }^{142}$ or public opinion surveys that a majority of respondents think there are excessive cash settlements. ${ }^{143}$

For Graycar the corrective of 'reform by frozen chook' is evidence and independent scholarly, peer-reviewed research. ${ }^{144}$ So too Saks saw the corrections for factoids was actual empirical evidence about the tort litigation system. ${ }^{145}$ In many respects both are suggesting that law reformers gather data, undertake their own analysis and engage significantly with existing, relevant, academic literature. Indeed, much of the rhetoric of the Commission about evidence and robust quantitative measures accords with this perspective. Graycar is not entirely discounting consultation and submission processes. Rather, her perspective is one of balance - that the frozen chookness of submissions and consultations, of a tendency to sectionalism, bare assertion, factoids, anecdote and unreliability - needs to be offset by empirical and verifiable evidence. Thus, in her view, reform commissions need to give equal weight to evidence in a narrow sense - being evidence that is empirical, quantitative and verifiable - and consultation.

However, this is not what the data of this study found in relation to Commission reports. This study found that consultation has been used by the Commission, particularly in the more social policy contexts, as evidence. This expands the definition of evidence away from the narrower concept of empirical, quantitative and verifiable evidence on which the Commission claims to primarily rely. Simply put, this study has found that 83 per cent of the sources used by the Commission to justify a recommendation were submissions.

\footnotetext{
${ }^{138}$ Barnett (2011), p 173.

${ }^{139}$ Saks (1992).

${ }^{140}$ Saks (1992), p 1162.

${ }^{141}$ See Rostron (2012) for the subsequent development of meanings of factoid since Saks.

${ }^{142}$ Graycar (2000), p 753; Graycar (2012), p 267.

${ }^{143}$ Saks (1992), p 1163.

${ }^{144}$ Graycar (2005), pp 49-77, 67-69.

${ }^{145}$ Saks (1992), pp 1167-69.
} 
Submissions, notwithstanding Graycar's perspective, need not always be akin to frozen chook. Submissions can present relevant evidence beyond factoids such as actual data, modelling or summarise existing literature. This is why we went further and investigated the actual material embedded in the source that the Commission was approving or adopting. In doing this, it became clear that very few of the recommendations were based on material that could be described as evidence in the narrow sense. As set out in Figure 4 only 9 per cent of recommendations are supported by empirical evidence and 5 per cent based on economic arguments. This means that only 14 per cent of recommendations from our sample were based on material that fits comfortably within the narrower definition of evidence, and within the particular expertise that the Commission, in its own rhetoric, claims for itself.

More significantly, 23 per cent of recommendations were based on a mere assertion; that is an unverified statement of fact. A further 5 per cent were based on statements drawn from personal experience. We do not question the veracity and genuine belief of those who have provided this material to the Commission. However, we do note that this indicates that 28 per cent of the recommendations were justified by material akin to either the sort of anecdotal tale-telling that Graycar identifies as frozen chook or factoids directed to the bare interests of those making submissions. This can only be considered 'evidence' if an extremely liberal interpretation is placed on the word. In particular, it is not the kind of 'evidence' that the Commission highlights as important in its own rhetoric.

This leaves the 58 per cent of recommendations that were based on logical or legal arguments. How this second order reasoning and its conclusions relate to 'evidence' is difficult to discern. At one level, if the Commission simply adopts a conclusion based on a logical or legal argument presented by stakeholder, then it is difficult to see how this is different from adoption of an assertion or a personal statement; the Commission is acting as a conduit for a stakeholder's reasoning to become a recommendation. If the Commission in its text examines, checks and compares that argument before adopting it, then it is possible to see the process as more analytical and objective. It would not necessarily be evidence as narrowly conceived, but it would satisfy critics like Graycar whose critique calls for transparency, verification and analysis in reform commission reports. ${ }^{146}$ However, there is no reason to believe that the Commission has greater expertise in analysing these arguments compared to a law reform commission. Particularly where the legal arguments are technical, its expertise is likely to be less, with greater reliance on the legal analysis conducted by the submitting party. However, such a comparison would be a matter for further research.

This is not to suggest that the Commission's recommendations are only ever supported by a single source containing a single argument. For example recommendation 6.4 in Australia's Anti-Dumping and Countervailing System advised that 'there should be no change to the current five-year default term for anti-dumping and countervailing measures', extensions should be limited to a single three-year term based on the same requirements as the original application and continuation reviews 'should, in all cases, comprehensively examine and recalculate the relevant variable factors' ${ }^{147}$ Focusing on where the Commission discusses the first element of this recommendation - the

\footnotetext{
${ }^{146}$ Graycar (2005), pp 49-77, 67-69.

${ }^{147}$ Productivity Commission (2009), p xxx, 116.
} 
no changes to the five-year default term - it is accompanied by a citation to submissions from the Australian Dried Fruits Association, Bluescope Steel, CSR, PolyPacific and Townsend Chemicals, SCA Hygiene and the Trade Remedies Task Force. Examining arguments contained in the cited submissions, Australian Dried Fruits Association, BlueScope Steel, SCA Hygiene and Trade Remedy Task Force all supported the current regime, presenting logical arguments relating to reasonableness of the period to allow recovery of affected industries. ${ }^{148}$ CSR argued that five years was needed to recuperate costs associated with applications to the Anti-Dumping regime $^{149}$ and PolyPacific and Townsend Chemicals merely asserted that it supported the existing scheme. ${ }^{150}$ The Commission then affirmed the 'efficacy of ... the current arrangements', ${ }^{151}$ adopting the logical argument presented by the approved submitters that five years is an appropriate balance between costs of application and impact on the market, and concludes that the 'current five-year default term for the initial imposition of measures is not unreasonable'. ${ }^{152}$ What is striking about this example is that, notwithstanding the closeness of the topic to the Commission's mission of markets and productivity, there is no recourse either by the Commission directly or in the submissions that were cited, to economic data or modelling. While other elements of the recommendation relating to extension were discussed in more detail, particularly how submitters disagreed with proposals in the draft report, ${ }^{153}$ the suggestion from the submissions that the current five-year term is logically an acceptable balance is channelled by the Commission into a recommendation with little analysis.

This example has not been presented to make the argument that recommendation 6.4 is in some way wrong; nor is it the argument that it was inappropriate for the Commission to ground its recommendation on submissions that made logical arguments. What has been shown in this example is the story of the findings of this study. From our analysis of the sample, when the Commission writes in a report about its recommendations, it tends to cite predominately from submissions and the 'evidence' relied upon tends to be of logical or legal nature or assertions. This 'evidence as consultation' seems removed from the Commission's rhetoric, in particular statements to the effect that it is in the business of making recommendations based on rigorous, quantifiable data. This reliance on evidence more broadly understood to include stakeholder's arguments and assertions runs the risk of anecdotal-ism and stakeholder preferences, whereby recommendations for reform seem to be based on sectorial and unverifiable information. The correction to this impression is implicit in the Commission's own rhetoric of 'evidence and consultation' where there can be extrapolated a transparent two stage process. First, the principal, motive or broad form of a recommendation is justified in terms of evidence in the form of data, modelling and secondary literature. Second, there is then a process whereby the specific form of the recommendation is shown to have emerged from an engagement with the consultation process. In that model, the result is a recommendation that is justified by evidence in

\footnotetext{
${ }^{148}$ Australian Dried Fruits Association (2009), p 5; BlueScope Steel (2009), p 17; Trade Remedies Task Force (2009), p 35; SCA Hygiene (2009), p 2.

${ }^{149}$ CSR Limited (2009), p 5.

${ }^{150}$ PolyPacific and Townsend Chemicals (2009), p 7.

${ }^{151}$ Productivity Commission (2009), p 111.

${ }^{152}$ Productivity Commission (2009), p 112.

${ }^{153}$ Productivity Commission (2009), pp 114-116.
} 
the narrow sense, but is also subject to rigorous scrutiny in the public arena. Within the reports there are many suggestions that this is the process that has occurred. However, this study has identified that, when it came to the texts of the reports, the second stage has often superseded the first.

In summary, it appears from our findings - based on our sample - that where recommendations are set out by the Commission, there is strong recourse to submissions and logical/legal arguments. From this, we suggest that the Commission, notwithstanding the rhetoric regarding empirical and quantifiable data, takes a broad view of 'evidence' to include arguments made in submissions. Although, more analysis needs to be undertaken on a wider sample of Commission reports, this study suggests that the Commission takes a 'consultation as evidence' approach.

\section{Conclusion}

This article grew out a desire to test the possibility that the Commission, by focusing on quantitative and empirical evidence, could be a different engine for law reform. In particular the Commission, in its rhetoric, seemed to be the answer to Graycar's critique of law reform commissions. We anticipated that its reports would disclose an empirical and quantitative approach that was linked to clear analysis of data and secondary literature and that this would be different to the community consultation approach used by law reform commissions. We explored the extent to which different types of evidence impact the Commission's recommendations, relying on the Commission's written explanations of its reasoning from inquiry reports combined with an analysis of the material cited. Our findings did not match our expectations. Our study found that the profile of evidence on which the Commission relied differs from what one might expect based on the rhetoric surrounding the Commission's approach. In particular, there is a tendency to treat submissions as evidence, even where they contain bare assertions or nonempirically tested anecdotes. This is particularly so where the Commission is conducting an inquiry on social policy issues that require it to work outside its traditional expertise in economics and markets.

Our findings are not intended to imply that reform commissions generally, or the Commission in particular, have not made an important contribution to policy debates in Australia. That would require an analysis of individual inquiries, rather than a broad-based study such as that conducted here. We are also not suggesting that a detailed and rigorous engagement with submissions is inappropriate. We do, however, emphases Graycar's concern with frozen chooks and Saks with factoids in relation to this material - that it can be sectorial, anecdotal and unverifiable. Thus, we do hope that politicians, the public and the Commission itself gain a better understanding of the Commission's methodology than that offered by reading its annual reports or listening to speeches given by its chairs (past and present). We would like for our work to prompt the Commission to reflect on its own understanding of its approach, and for others to provide more rigorous testing of our preliminary conclusions. We also wish to prompt a broader debate about the role of the Commission, particularly in relation to its work in fields of social policy that require it to look beyond quantitative, empirically verified evidence. 


\section{ORCID}

Lyria Bennett Moses (D) http://orcid.org/0000-0003-2571-1469

Kieran Tranter (D) http://orcid.org/0000-0003-1683-2939

\section{Acknowledgements}

The authors would like to thank Ashley Pearson for assistance with the final manuscript, as well as the anonymous reviewers for their helpful comments.

\section{References}

Primary Sources

Commonwealth, Parliamentary Debates, House of Representatives, 4 December 1996, p 7720

(Chris Miles, Parliamentary Secretary (Cabinet) to the Prime Minister).

Productivity Commission Act 1998 (Cth).

Productivity Commission (Repeals, Transitional and Consequential Amendments) Act 1998 (Cth).

Secondary Sources

Gary Banks (2010) An Economy-Wide View: Speeches on Structural Reform, Productivity Commission.

Gary Banks (2012) Advancing the Reform Agenda: Selected Speeches, Productivity Commission.

Laura Barnett (2011) 'The Process of Law Reform: Conditions for Success' 39 Federal Law Review 161.

Becky Batagol and Melissa Castan (2012) 'Did You Know ... Citations, Sources and References' 37(1) Alternative Law Journal 50.

Michael Beaird (2002) 'Citations to Authority by the Arkansas Appellate Courts, 1950-2000' 25 University of Arkansas at Little Rock Law Review 301.

Fred Brenchley (2008) 'In Search of a Mission', Business Review Weekly (Sydney), 14 February 2008.

Dragomir Cosanici and Chris Evin Long (2005) 'Recent Citation Practices of the Indiana Supreme Court and the Indiana Court of Appeals' 24 Legal Reference Services Quarterly $103-119$.

Ian Davis (2005) 'Targeted Consultations' in B Opeskin and D Weisbrot (eds) The Promise of Law, Federation Press.

Dietrich Fausten, Ingrid Nielsen and Russell Smyth (2007) 'A Century of Citation Practice on the Supreme Court of Victoria' 31 Melbourne University Law Review 733.

Dietrich Fausten and Russell Smyth (2008) 'Coordinate Citations Between Australian State Supreme Courts over the 20th Century' 34 Monash University Law Review 53.

Lawrence M Friedman et al (1981) 'State Supreme Courts: A Century of Style and Citation' 33 Stanford Law Review 773.

Tracey George and Chris Guthrie (1999) 'An Empirical Evaluation of Specialized Law Reviews' 26 Florida State University Law Review 813.

Regina Graycar (2000) 'Law Reform by Frozen Chook: Family Law Reform for the New Millennium?' 24(3) Melbourne University Law Review 737.

Regina Graycar (2005) 'Frozen Chooks Revisited: The Challenge of Changing Law/s' in R Hunter and M Keyes (eds) Changing Law: Rights, Regulation and Reconciliation, Ashgate.

Regina Graycar (2012) 'Family Law Reform in Australia, or Frozen Chooks Revisited Again?' 13(1) Theoretical Inquiries in Law 241.

Regina Graycar and Jenny Morgan (2005) 'Law Reform: What's in It for Women?' 23 Windsor Yearbook of Access to Justice 30.

Peter Harris (1985) 'Ecology and Culture in the Communication of Precedent among State Supreme Courts, 1870-1970' 19 Law and Society Review 449. 
Peter Harris (2013) 'The Productivity Reform Outlook - Creating an Expectations Effect in Support of Continuous Reform' http://www.pc.gov.au/news-media/speeches/reformoutlook/20130501-reform-outlook.pdf, 19 October 2015.

House of Representatives, Commonwealth Parliament (1996) Explanatory Memorandum: Productivity Commission Bill 1996 (Cth).

William H Hurlburt (1986) Law Reform Commissions in the United Kingdom, Australian and Canada, Juriliber.

Charles A Johnston (1985) 'Citation to Authority in Supreme Court Opinions' 7 Law and Policy 509-523.

Frederick N Judson (1910) ‘A Modern View of the Law Reforms of Jeremy Bentham' 10 Columbia Law Review 41.

Michael Kirby (1983) Reform the Law: Essays on the Renewal of the Australian Legal System, Oxford University Press.

Richard G Kopf (1997) 'Do Judges Read the Review - A Citation-Counting Study of the Nebraska Law Review and the Nebraska Supreme Court, 1972-1996' 76 Nebraska Law Review 708.

Paul Krugman (1992) Age of Diminished Expectations: US Economic Policy in the 1980s, MIT Press.

William M Landes and Richard A Posner (1995) 'The Most-Cited Law Review Articles Revisited' 71 Chicago-Kent Law Review 825.

Bruno Latour (2010) The Making of Law: An Ethnography of the Conseil d'Etat, Polity.

Charles Lawson (2008) 'Public Interest Compulsory Licensing under the Patents Act 1990 (Cth): A Real Incentive or a Barrier to Working? 19(3) Australian Intellectual Property Journal 129.

Roderick MacDonald (1997) 'Recommissioning Law Reform' 35 Alberta Law Review 831.

Roderick MacDonald (2008) 'Jamais Deux Sans Trios ... Once Reform, Twice Commission, Thrice Law' 22 Canadian Journal of Law and Society 117-143.

Ian Manning (1998) 'Alternative to the Productivity Commission's Model' 41 National Economic Review 6.

William H Manz (1995) 'The Citation Practices of the New York Court of Appeals, 1850-1993' 43 Buffalo Law Review 121.

William H Manz (2001) 'The Citation Practices of the New York Court of Appeals: A Millennium Update' 49 Buffalo Law Review 1273.

Olavi Maru (1976) 'Measuring the Impact of Legal Periodicals' 1 Law and Social Inquiry 227-250.

Peter McCormick (1996a) 'The Supreme Court Cites the Supreme Court: Follow-Up Citation on the Supreme Court of Canada, 1989-1993' 33 Osgoode Hall Law Journal 453.

Peter McCormick (1996b) 'Judicial Citation, the Supreme Court of Canada, and the Lower Courts: The Case of Alberta' 34 Alberta Law Review 870.

Peter McCormick and Tammy Praskach (1996) 'Judicial Citation, the Supreme Court of Canada, and the Lower Courts: A Statistical Overview and the Influence of Manitoba' 24 Manitoba Law Journal 335.

Angela Melville (2007) 'Conducting Law Reform Research: A Comparative Perspective' 28 Zeitschrift für Rechtssoziologie 153.

John Henry Merryman (1978) 'Toward a Theory of Citations: An Empirical Study of the Citation Practice of the California Supreme Court in 1950, 1960, and 1970' 50 Southern California Law Review 381.

Marcia Neave (2007) 'Making Law Reform Work - The Promise and Limits of Law Reform' 14 James Cook University Review 19.

Ingrid Nielsen and Russell Smyth (2008) 'One Hundred Years of Citation of Authority on the Supreme Court of New South Wales' 31 University of New South Wales Law Journal 189.

Brian Opeskin (2002) 'Engaging the Public - Community Participation in the Genetic Information Inquiry' 80 Reform 53.

Brian Opeskin (2005) 'Measuring Success' in B Opeskin and D Weisbrot (eds) The Promise of Law, Federation Press.

Brian Opeskin and David Weisbrot (eds) (2005) The Promise of Law Reform, Federation Press. 
Kevin Purse, Robert Guthrie and Frances Meredith (2004a) 'Faulty Frameworks: The Productivity Commission and Workers' Compensation' (2004) 17 Australian Journal of Labour Law 306.

Kevin Purse, Frances Meredith and Robert Guthrie (2004b) 'Neoliberalism, Workers' Compensation and the Productivity Commission' 54 Journal of Australian Political Economy 45.

Ian Ramsay and G P Stapledon (1997) 'A Citation Analysis of Australia Law Journals' 21 Melbourne University Law Review 676.

Allen Rostron (2012) 'Factoids' 16 Green Bag 43.

Ronald Sackville (1983) 'Law Reform - Limitations and Possibilities' in A Blackshield (ed) Legal Change: Essays in Honour of Julius Stone, Butterworths.

Michael J Saks (1992) 'Do We Really Know Anything about the Behavor of the Tort Litigation System - And Why Not?' 140 University of Pennsylvania Law Review 1147.

Robert Samek (1977) 'A Case for Social Law Reform' 55 Canadian Bar Review 409.

Robert Schriek (1991) 'Most-Cited U.S. Courts of Appeals Cases from 1932 until the Late 1980s' 83 Law Library Journal 317.

Fred R Shapiro (1985) 'The Most-Cited Law Review Article' 73 California Law Review 1540.

Fred R Shapiro (1991) 'The Most-Cited Articles from the Yale Law Journal' 100 Yale Law Journal 1449.

Fred R Shapiro (1995) 'The Most-Cited Law Review Articles Revisited' 71 Chicago-Kent Law Review 751.

Louis J Sirico and Beth A Drew (1991) 'The Citing of Law Reviews by the United States Courts of Appeals: An Empirical Analysis' 45 University of Miami Law Review 1051.

Judith Sloan (2011) 'How Useful Is the Productivity Commission?' 27(1) Policy 31.

Russell Smyth (1999a) 'Other than "Accepted Sources of Law"?: A Qualitative Study of Secondary Source Citations in the High Court' 22 University of New South Wales Law Journal 19.

Russell Smyth (1999b) 'Academic Writing and the Courts: A Quantitative Study of the Influence of Legal and Non-legal Periodicals in the High Court' 17 University of Tasmania Law Review 164.

Russell Smyth (1999c) 'What Do Judges Cite? An Empirical Study of the "Authority of Authority" in the Supreme Court of Victoria' 25 Monash University Law Review 29.

Russell Smyth (1999d) 'What Do Intermediate Appellate Courts Cite? A Quantitative Study of the Citation Practice of Australian State Supreme Courts' 21 Adelaide Law Review 51.

Russell Smyth (2000a) 'Who Gets Cited? An Empirical Study of Judicial Prestige in the High Court' 21 University of Queensland Law Journal 7.

Russell Smyth (2000b) 'The Authority of Secondary Authority: A Quantitative Study of Secondary Source Citations in the Federal Court' 9 Griffith Law Review 25.

Russell Smyth (2001a) 'Citation of Judicial and Academic Authority in the Supreme Court of Western Australia' 30 University of Western Australia Law Review 1.

Russell Smyth (2001b) 'Judicial Prestige: A Citation Analysis of Federal Court Judges' 6 Deakin Law Review 120.

Russell Smyth (2002) 'Judges and Academic Scholarship: An Empirical Study of the Academic Publication Patterns of Federal Court and High Court Judges' 2 Queensland University of Technology Law and Justice Journal 198.

Russell Smyth (2007) 'The Citation Practices of the Supreme Court of Tasmania, 1905-2005' 26 University of Tasmania Law Review 34.

Russell Smyth (2008a) 'A Century of Citation: Case-Law and Secondary Authority in the Supreme Court of Western Australia' 34 University of Western Australia Law Review 145.

Russell Smyth (2008b) 'Citation to Authority on the Supreme Court of South Australia: Evidence from a Hundred Years of Data' 29 Adelaide Law Review 113.

Russell Smyth (2009a) 'Trends in the Citation Practice of the Supreme Court of Queensland over the Course of the Twentieth Century' 28 University of Queensland Law Journal 39.

Russell Smyth (2009b) 'Citing Outside the Law Reports: Citations of Secondary Authorities on the Australian Supreme Courts over the Twentieth Century' 18 Griffith Law Review 692-726.

Russell Smyth (2012) 'Who Publishes in Australia's Top Law Journals?' 35 University of New South Wales Law Journal 201.

Kenneth Sutton (1970) The Pattern of Law Reform in Australia, University of Queensland Press. 
Kieran Tranter (2015) 'Citation Practices of the Australian Law Reform Commission in Final Reports 1992-2012' 38(1) University of New South Wales Law Journal 316-361.

Tania Voon and Andrew D Mitchell (1998) 'Professors, Footnotes and the Internet: A Critical Examination of Australian Law Reviews' 9 Legal Education Review 1.

Ken Waller (2012) 'Opportunities Abound for Australia in Taiwan' http://theconversation.com/ opportunities-abound-for-australia-in-taiwan-11134, 19 October 2015.

David Weisbrot (2005) 'The Future of Institutional Law Reform' in B Opeskin and D Weisbrot (eds) The Promise of Law, Federation Press.

Submissions

Australian Customs and Border Protection Service, Submission 33 to Australian Productivity Commission, Australia's Anti-dumping and Countervailing System, 16 July 2009.

Australian Dried Fruits Association, Submission No 14 to Australian Productivity Commission, Australia's Anti-dumping and Countervailing System, 26 June 2009.

Australian Energy Market Operator, Submission DR100 to Australian Productivity Commission, Electricity Network Regulatory Frameworks, 16 January 2013.

Australian Institute of Superannuation Trustees, Submission DR69 to the Australian Productivity Commission, Default Superannuation Funds in Modern Awards, 3 August 2012.

BlueScope Steel, Submission No DR55 to Australian Productivity Commission, Australia's Anti-dumping and Countervailing System, 9 November 2009.

Clare Dewan and Associates, Submission 119 to Australian Productivity Commission, Caring for Older Australians, 29 July 2012.

CSR Limited, Submission No 10 to Australian Productivity Commission, Australia's Antidumping and Countervailing System, 25 June 2009.

International Monetary Fund (2014) Norway: Selected Issues Paper Report 14/260.

PolyPacific and Townsend Chemicals, Submission No DR51 to Australian Productivity Commission, Australia's Anti-dumping and Countervailing System, 6 November 2009.

SCA Hygiene, Submission No DR60 to Australian Productivity Commission, Australia's Antidumping and Countervailing System, 9 November 2009.

Trade Remedies Task Force, Submission No 26 to Australian Productivity Commission, Australia's Anti-dumping and Countervailing System, 26 June 2009.

Reports

Australian Law Reform Commission (1996) Making Rights Count: Services for People with a Disability - New Disability Services Legislation for the Commonwealth - Review of Legislation Administered by the Department of Health and Family Services, Report No 79.

Australian Law Reform Commission and Australian Health Ethics Committee of the National Health and Medical Research Council (2003) Essentially Yours: The Protection of Human Genetic Information in Australia, Report No 96.

Australian Law Reform Commission (2008) For Your Information: Australian Privacy Law and Practice, Report No 108.

Australian Law Reform Commission (2011-12) Annual Report Report No 119.

Australian Law Reform Commission (2012-13) Annual Report Report No 121.

Australian Law Reform Commission and New South Wales Law Reform Commission (2010) Family Violence: A National Legal Response, Report No 114.

Australian Law Reform Commission (2013-14) Annual Report Report No 125.

Organisation for Economic Co-operation and Development (2010) OECD Review of Regulatory Reform: Australia - Towards a Seamless National Economy.

Organisation for Economic Co-operation and Development (2011) Economic Surveys Germany.

Organisation for Economic Co-operation and Development (2013) Economic Surveys Mexico.

Productivity Commission (1997-98) Annual Report.

Productivity Commission (2003) From Industry Assistance to Productivity: 30 Years of 'the Commission.

Productivity Commission (2005-06) Annual Report.

Productivity Commission (2006-07) Annual Report.

Productivity Commission (2008-09) Annual Report.

Productivity Commission (2009) Australia's Anti-dumping and Countervailing System, Inquiry Report No 48.

Productivity Commission (2009-10) Annual Report. 
Productivity Commission (2010-11) Annual Report.

Productivity Commission (2011a) Caring for Older Australians, Inquiry Report No 53.

Productivity Commission (2011b) Disability Care and Support, Inquiry Report No 54.

Productivity Commission (2012) Default Superannuation Funds in Modern Awards, Inquiry Report No 60.

Productivity Commission (2012-13) Annual Report.

Productivity Commission (2013a) Compulsory Licensing of Patents, Inquiry Report No 61.

Productivity Commission (2013b) Electricity Network Regulatory Frameworks, Inquiry Report No 62.

Productivity Commission (2013c) Major Project Development Assessment Processes, Research Report.

Productivity Commission (2013-14) Annual Report. 